\title{
Soldiers as Traditionalizers
}

\author{
Military Rule and the Re-Africanization of Africa*
}

\author{
ALI A. MAZRUI \\ The University of Michigan, Ann Arbor, U.S.A.
}

\begin{abstract}
$\mathrm{A}_{\mathrm{N}}$
EARLIER generation of political scientists working on Africa tended to draw from their work in West Africa conclusions about black Africa as a whole. Much of what occurred in West Africa was regarded as evidence of likely trends elsewhere in the continent. Such predictions were sometimes vindicated. The growth of modern nationalism in West Africa from the 1930's onwards did spread to other parts of Africa. The emergence of one-party systems in West Africa found imitators within a few years in other African countries. Even the application of a particular analytical concept to a West Africa situation - like David E. Apter's analysis of Kwame Nkrumah as a "charismatic leader" - soon led to a more dubious scramble to identify other "charismatic" figures in Tanzania, Zambia, Kenya, Malawi, Uganda and elsewhere. ${ }^{1}$

If on at least some matters West Africa once provided evidence of likely trends elsewhere on the continent, is it possible that East Africa's experience in other domains might now be similarly assessed as a traffic indicator for the rest of the continent? Are there aspects of recent East African history which should raise questions about likely trends in other African regions?

What is at stake is partly the methodology of hypothesizing, perhaps as part of the methodology of research. Would it be fruitful to frame a hypothesis for testing in Gabon or Niger on the basic conclusions drawn from research in Uganda? As a comparative Africanist this author is of the opinion that comparative politics as a whole means nothing if it does not include readiness to use evidence from one part of Africa as potential material for formulating Africa-
\end{abstract}

- This paper was originally presented at the annual convention of the Canadian Association of African Studies, York University, Canada, February 1975. A version of it has since been published in World Politics, Vol. XXVIII, No. 2, 1976.

1 Influential works of that period include James S. Coleman, "Nationalism in Tropical Africa", The American Political Science Review, XLVII, No. 2, June 1954; Coleman, Nigeria : Background to Nationalism; David E. Apter, The Gold Coast in Transition (Princeton: Princeton University Press, 1955); Gabriel Almond and James S. Coleman (eds.) The Politics of the Developing Areas (Princeton: Princeton University Press, 1960) and Martin Kilson "Authoritarian and Single-Party Tendencies in African Politics," World Politics Vol. 15 No. 2 January 1963. 
wide hypotheses. It would then be up to other researchers to test some of these hypotheses against empirical findings elsewhere in the continent.

The recent behaviour and policies of a number of military regimes in Africa are raising new questions about the role of the military in the dialectic between tradition and modernity. My own most concentrated research on this subject has focussed on Uganda, but the Ugandan experience raises wider questions which other researchers elsewhere may wish to pursue further. This is particularly so when we allow for the possibility that the Ugandan experience may be less unique than the personality of Idi Amin may at first give us to understand.

If General Idi Amin of Uganda is indeed as "atavistic" as he seems to be, can he also be a modernizer? Is the cultural nationalism of General Mobuto Sese Seko of Zaire developmental or retrograde? Is General Bokassa of the Central African Republic an incongruous warrior in the wrong century? Is Colonel Quaddafy of Libya anachronistic? Before we grapple with these issues, let us first return to an older generalization.

\section{An Older Hypothesis: Soldiers as Modernizers}

The 1960's witnessed among social scientists an increasing belief that the armed forces were agents of modernization. An early convert to this view was Lucian W. Pye. Pye drew a legitimate distinction between the army as a modern organization and the army as a modernizing force. He conceded that the status of the army as a modern organization was clearer than its modernizing impact on the rest of the society. He saw the military establishment as something which came "as close as any human organization can to the ideal type of an industrialized and secularized enterprise." Most of the colonial armies were based on western military technology, and had used the World War II type of army as their model. To that extent they had utilized a form of organization peculiar to a highly industrialized civilization. The need for discipline within the armed forces, the necessity for them to relate means to ends, the need for technical skills and co-ordination of effort, all converted the military establishment into a modern organization.

The question which arose was whether it was also a modernizing agency, helping to change the rest of the society away from traditionalist preconceptions and towards a pattern of behaviour more characteristic of modern societies. On balance, Pye was optimistic about the modernizing capabilities of the armed forces in developing countries. ${ }^{2}$

This approach to the study of the military was applied more directly to African situations by a number of scholars, and continued to influence scholarly assessments of the impact of the military in African societies right into the the 1970's. Ernest E. Lefever put the point of view at its most extravagant when he asserted:

2 Lucian W. Pye, "Armies in the Process of Political Modernization," in The Role of the Military in Underdeveloped Countries, edited by John J.Johnson (Princeton University Press, 1962) pp. 80-89. 


\begin{abstract}
"African armies tend to be the most detribalized, westernized, modernized, integrated, and cohesive institutions in their respective States. The army is usually the most disciplined agency in the State. It often enjoys a greater sense of national identity than other institutions. In technical skills, including the capacity to coerce and to communicate, the army is the most effective agency in the country... A more vivid symbol of sovereignty than the flag, the constitution, or the parliament, the army often evokes more popular sentiment than a political leader."33
\end{abstract}

But voices of dissent concerning the developmental capability of the armed forces have increasingly been heard. Sometimes these voices distinguish between modernization and political development. The same voices might concede that the soldiers were indeed agents for modernization without necessarily accepting that they therefore contributed towards the political development of their societies. This Huntingtonian distinction between modernization and political development has been quite influential. Modernization has been viewed as the complex process of social and economic change caused by and manifested in the growth of new towns and cities, the spread of mass education, the extension of mass communication, and the process of industrialization. Political development, on the other hand, is seen as the process by which a society acquires an institutional capability to handle the political and social pressures which are generated by the process of modernization.

It is conceivable for the military to play a critical economic role which speeds up industrialization and accelerates urbanization. There have been military regimes which, because they were less socialistically oriented than the civilian governments they overthrew, and because they were more concerned with bread-and-butter issues than with long term ideological formulations, have performed better economically than their predecessors. New links strengthened with the western world, greater encouragement of investment, greater promotion of indigenous enterprise, have in such cases helped to accelerate both urbanization and industrialization. In this special sense then, such regimes might be deemed to have contributed to the modernization process. And yet, if part of the effect of these changes is to make the construction of viable and legitimate political institutions more difficult than ever, and create the potentiality of social and economic restlessness on a wide scale, it could indeed be inferred that the modernizing impact of the military is not necessarily in the direction of consolidating political development.

But even on the modernizing front, voices have questioned whether the

3 Ernest W. Lefever, Spear and Sceptre: Army, Police and Parliament in Tropical Africa (Washington: The Brookings Institution, 1970) p. 21. For a prophetically more cautious approach see Morris Janowitz, The Military in the Political Development of New Nations: An Essay in Comparative Analysis (Chicago: University of Chicago Press, 1964). For further comparative purposes consult Daniel Lerner and Richard D. Robinson, "Swords and Plough-Shares: The Turkish Army as a Modernizing Force," World Politics, Vol. xii No. 1, October 1960, pp. 19-44, and Manfred Halpern, The Politics of Social Change in the Middle East and North Africa (Princeton: Princeton University Press, 1963) especially pp. 251-280. 
military were indeed any more effective than their civilian counterparts in developing countries. In the words of Claude E. Welch:

"It is clear that the armed forces have not fulfilled the predictions of some social scientists, put forward during the early 1960's, that their organization, modernity and nationalism would make them the leaders of the modernization process in their countries. On the other hand, their performance as rulers in this regard has possibly not been much worse than that which might have been achieved by the available civilian alternatives." 4

Across the Atlantic in Britain, J. M. Lee was sceptical about the modernizing effect of military rule even earlier. He did not see African armies as being necessarily motivated by a desire to provide efficient administration.

"There is little evidence to indicate that African armies make better instruments of 'modernization' than their civil servant counterparts. Indeed, all the organizations of the State appear to face a common threat of problems."5

Our own purpose in this paper is to take the discussion even further. We propose neither to assert the modernizing impact of the armed forces, nor to claim that the armed forces are no different from that point of view from their civilian counterparts. There is a third area of investigation which needs to be undertaken with special regard to African soldiers. This area is captured by the following questions: are African soldiers agents for retraditionalization? are they carriers of values that might contribute to a partial resurrection of indigenous political cultures? are African soldiers agents for the grand process of the re-Africanization of Africa at a new level?

As I indicated, most of my own field work has been in East Africa, sometimes as a participant observer in national politics, especially in Uganda. My findings indicate that there may indeed be a traditionalizing role for military rulers in Africa. This proposition is not inconsistent with the assertion that there might also be a concurrent and paradoxical modernizing role. In situations of cultural and institutional fluidity, the impact of the soldiers could be multi-variant, and might carry significant sociological contradictions. My own position in this research note is that we do not know as yet whether or not African soldiers are better modernizers than African politicians, but there is increasing evidence to suggest that they may be greater traditionalizers than their old civilian counterparts. It is conceivable for the modernizing competitive records of politicians and soldiers to be evenly balanced, while the contradictory but concurrent record of renewing faith in certain aspects of traditional culture

4 See Claude E. Welch, Jr. and Arthur K. Smith, Military Role and Rule: Perspectives on Civil-Military Relations (North Scituate, Massachusetts: Duxbury Press, 1974) p. 256. Welch has pointed out elsewhere that the "modern" organizational characteristics of the armed forces could readily break down after the army has captured power. "In short, coup leaders face the same difficulties over which their civilian predecessors stumbledwithout necessarily benefitting from greater advantages." Claude E. Welch, Jr., (editor) Soldier and State in Africa: A Comparative Analysis of Military Intervention and Political Change (Evanston, Northwestern University Press, 1970) p. 59.

5 J. M. LeE, African Armies and Civil Order (London: Chatto and Windus for the Institute for Strategic Studies, 1969) p. 184. 
remains one which gives greater weight to the performance of the men in uniform.

Western commentators who have often discerned a conservative streak in "the military mind" in their own societies have at times chosen to ignore this when analyzing the role of the armed forces in developing countries.

We shall first address oursclves to this theme of conservatism as it relates to the behaviour of African soldiers in situations of culture conflicts and normative fluidity. We shall then examine the degree to which "retribalization" under military rule in African countries is an aspect of retraditionalization. We shall then relate this to the rural origins of African soldiers and the relevance of these origins for the resurrection of certain aspects of indigenous political cultures. Finally, we propose to relate this whole discussion to the distinction between political development and political decolonization and the manner in which they are affected by the dialectic between westernization and African cultural nationalism.

\section{Political Conservatism and Social Tradition}

What happens when a military establishment based on western organizational concepts, and conditioned by a western approach to military professionalism, seeks to operate in the culturally different conditions of African societies? Certainly the military profession in its modern forms in African countries has overwhelmingly borne the stamp of the metropolitan power. In Uganda the organization of the armed forces was solidly patterned upon the British model. The whole military ritual, including the pattern of drill, the categories and terminology of ranks, and the very music of the armed forces, all remained defiantly British in tone and style. Occasions of military ceremony, ranging from the funeral of a former President to the celebration of independence, from the commemoration of a military event to a preparation for combat, have still retained their ancestral connection with the metropolitan power.

To the extent to which these rituals and British traditions are upheld, this could be seen as a form of conservatism. But clearly in relation to the values of African societies, such exercises in Anglocentric militarism are by definition a departure from the indigenous normative order, rather than an exercise in its conservation.

It was Edward Shils who captured in an early essay an important distinction with regard to the new military establishment in the developing countries. The military establishment, to the extent to which it was derived from western models, was by definition non-traditional. But this did not prevent the sympathies of soldiers from being in favour of local traditions. The military establishment might indeed be a modern organization, but the attitude of the soldiers to the wider society might be more deeply conditioned by traditionalist sympathies than by the modern characteristics of their particular profession. As Shils put it: 
"Military organization has little to do with the structure of traditional society, from which it is set off by its technology, most of its ethos, its organization, and its training-all of which are either imported or follow foreign models... Yet it probably remains a fact that the military have a feeling of sympathy for tradition, not only for their own military tradition but for the traditional style of society as well. Hierarchic dignity, respect for superiors, solicitude for subordinates, solidarity, and conventionality produce in professional soldiers an attachment to the same phenomena in civilian society. Their humble origins and their separation from urbanc pleasures and indulgences sustain this sympathy."

In a situation where the soldiers are recruited from among the least westernized of former colonial subjects, at times directly from the narrow world of villagers and their simple beliefs, this distinction between the military establishment as a modern organization and the individual soldier as a traditionalist could be of considerable dialectical implication.

Western analysts who have been concerned with "the military mind" have at times transferred the scientificity of the military organization and attributed it to the mind of the military man. In the formulation of Samuel Huntington:

"Military and civilian writers generally seem to agree that the military mind is disciplined, rigid, logical, scientific..."

Even if it were true that the military mind in the West was "logical and scientific" - Huntington himself is not absolutely sure - the field is still open for a Field Marshal Idi Amin in Uganda or a General Mobutu Sese Seko in Zaire to be "intuitive and even superstitious".

What is more likely is that the military establishments that these leaders have inherited from the colonial experience might indeed remain scientific at least with regard to technology, and logical with regard to systems of co-ordination, while the individual men in uniform remain relatively steeped in primordial beliefs and traditionalist tendencies. The military as an organization might in part be a carrier of scientificity, while the soldiers remain carriers of more primordial habits.

For as long as an African army is subordinate to civilian authority, and is consulted mainly on issues concerning security and the interests of the military organization, the impact of the traditionalism of individual soldiers on policymaking might be negligible. On the contrary, it might conceivably be the scientificity of the military organization that remains of most direct relevance to the society in a situation of civilian supremacy. The soldiers might be ordered to participate in nation-building and civic activities, and they may thus possibly have a demonstration effect in terms of co-ordination and discipline on at least sections of the wider society. What this means is that, in a situation where

6 Edward Shils, "The Military in the Political Development of New States," John J. Johnson (editor), The Role of the Military in Underdeveloped Countries, op. cit., p. 31. Consult also Henry Bienen, (ed.), The Military and Modernization (Chicago and New York: Aldine Atherton, 1971).

7 Huntington, The Soldier and the State (Cambridge, Massachusetts: The Belknap Press of Harvard University Press, 1967), p. 60. 
the soldiers have not as yet intervened and captured power, it is at most their "scientific and logical" ethos which reveals itself to the wider public.

But upon assumption of ultimate power, and the initiation of policy-making on a wide range of issues, do the more primordial aspects of their normative orientation acquire both greater feasibility and a greater impact on policy? The record in Africa so far is mixed but experience in Eastern Africa suggests a trend towards selective re-traditionalization.

Clearly this has connections with the rural origins of most African soldiers, and it is to this aspect that we must now turn.

\section{Turning Ploughshares into Swords}

This writer and others have drawn attention to the tendency for armies in developing countries to recruit from some of the least privileged sectors of the population. As the colonial presence consolidated itself, and new classes and social ranks began to emerge, there was a decline in the prestige of martial qualities.

The old days when warriorhood was, in many East African societies, a high status occupation were now receding into history. In some indigenous political systems the warrior stage was inseparable from the status of adulthood. Some societies linked the status to circumcision ceremonies, other societies invoked alternative methods of initiation. The moment of initiation marked a boy's transition, "From the culturally disvalued role of a boy... to the culturally valued role of the warrior."8

But three processes contributed to the decline of the warrior tradition under European colonial rule. One process was precisely connected with the discouragement of that tradition by both colonial administrators and Christian missionaries in East Africa. The colonial administrators had a vested interest in discouraging warriorhood for obvious reasons connected with a desire to monopolize the legitimate use of physical force in their colonies, and protect the stability of the colonial order. The Christian missionaries discouraged warriorhood partly because of a presumed inconsistency with Christian love, and partly because it was associated with the "heathen cultures" which the Christian gospel was out to eliminate.

A second process which helped to reduce the prestige of the warrior tradition concerned the intellectualization of African political culture under the impact of a more literate civilization. The coming of the written word in many East African societies, the establishment of missionary and state schools, and the rise of a white-collar class, all these competed effectively against the old indigenous prestige of warriorhood, and pulled young men in their millions towards classrooms indoors away from war dances in village compounds.

The third, and related process, concerned the economic diversification of

8 Satish Saberwal, The Traditional Political System of the Embu of Central Kenya (Nairobi: East African Publishing House for Makerere Institute of Social Research, 1970), p. 17. 
East African societies. Many of these societies no longer felt that the ultimate economic roles for young people lay either in settled agriculture or in herding cattle. There were now the additional opportunities of urban employment, work in the mines, jobs as domestic servants and farm assistants, and the whole range of white-collar occupations available to those who had acquired some of the literary skills of the new metropolitan culture.

Against this background of new opportunities, a job as a soldier even in a modern uniform and with guns rather than spears or bows and arrows, was now seldom at the top of the scale of preferences for ambitious young men. Those who could go to school, and move on towards white-collar jobs, normally preferred such prospects to the opportunities of being recruited into the army. The colonial armed forces therefore increasingly turned to the most disadvantaged sector of society for their soldiers.

There was a related factor which made colonial recruiting officers inclined more towards the less literate of their subjects for use in the armed forces. This was simply the conviction among many colonial administrators that illiterate or semi-literate East Africans made better soldiers than the better educated. The better educated were sometimes distrusted as "cheeky" and not adequately inclined towards the level of obedience that the armed forces required. An illiterate tribesman could, it was assumed, be trusted to be more automatically obedient than a product of a secondary school.

The less educated Africans were in their general orientation and attitude more rural than the educated. Indeed, western education in East African conditions was a process of psychological deruralization. The educated African became in a fundamental sense a rural misfit in his own village. His parents were often people who had made sacrifices to improve the career opportunities of their child. When he graduated from school, his parents did not expect him to continue living with them, tending the cattle, or cultivating the land. Many parents assumed that the whole purpose of education was occupational improvement. They were therefore inclined to regard any insistence on the part of their educated son to remain with them in their village as something approaching filial betrayal. If their son was going to remain in the rural areas, why were all those sacrifices necessary? White-collar jobs in the villages were few and far between, and precisely because of that their son would become a rural misfit.

The illiterate or semi-literate village boy, on the other hand, maintains a compatibility with his rural environment. And upon being recruited into the army, he takes into the armed forces many of the predispositions, attitudes and even superstitions that are characteristic of the rustic community from which he springs.

It is true that once the young rustic is himself in the army, he becomes subject to certain westernizing influences. After all, as we indicated, the army is still substantially organized on the basis of a western model, utilizes western military technology, and is partly influenced by western military values. Lucian Pye compares the acculturative impact of military training with the 
acculturative influences involved in the urbanization process. On balance, Pye regards the army as a more potent influence for culture change within individuals than living in a city.

On this issue Pye is less than persuasive. The range of influences at work in urban centres, partly because of their very diffuseness, might constitute a more potent force for psychological reorientation than military training per se. This is particularly so when the urbanization process is combined with formal education in a western type of school. The peasant boy who goes to the barracks and receives military training is primarily being inducted into new skills, and secondarily into new values. And even these new values are often limited to a small area of experience, the values of combat and military co-ordination, with a few derivative normative tendencies. Even after years of experience in the army, semi-literate or illiterate African soldiers are much further from a secondary school graduate living in a city in their level of westernization than Pye's assumptions might imply. The urbanized secondary school graduate is simply more comprehensively, and perhaps even more deeply, acculturated than the peasant warrior in uniform in the barracks. ${ }^{9}$

As for secondary school graduates who enter the armed forces, and later receive additional training, these in turn are on balance at a lower level of normative westernization than civilian university graduates in Africa.

Many of the first waves of African rulers were in some sense products of the intellectualization of political culture in the colonies. A few of those leaders, including such figures as Kwame Nkrumah and Milton Obote were basically intellectuals in their capacity to be fascinated by ideas and in their ability to handle some of those ideas effectively. Some of the soldiers who have replaced them bear a more modest impact of western intellectualization than they did.

From the point of view of the immediate risks to rational policy-making, and the utilization of careful intellectual criteria in determining policy choices, the fact that most military leaders are less intellectual than their civilian predecessors might have a political cost. On the other hand, from the point of view of the long-term reduction of intellectual dependency in Africa and the partial resurrection of indigenous cultural ways, the soldiers might prove to be greater agents for the re-Africanization of Africa than their civilian predecessors.

Scholars like Aristide R. Zolberg have therefore been mistaken in their refusal to recognize any significant differences between military and civilian rulers in African conditions.

"Beneath their uniforms, the Gowans, Lamizanas, Bokassas, and Mobutus are men with the same range of virtues and vices, wisdom and foolishness as the Balewas, Olympios, Yameogos, and Nkrumahs they replaced.... As a category, the military governors of Africa are unlikely to rule better, or more justly, or more effectively than their civilian predecessors." 10

9 Lucian W. Pye, "Armies in the Process of Political Modernization," op. cit., pp. 81-83.

10 Zolberg, "The Military Decade in Africa," a review article, World Politics, Vol. XXV, No. 2, January 1973, p. 319. 
In fact, the range of vices and virtues has not been identical. On balance, the level of political brutality and violent sanctions against offenders has been higher under military rule in countries like the Central African Republic, Uganda, and in a special sense even Nigeria. The invocation of physical force had tended to increase in such countries. It is therefore not clear why we should not regard this as a moral cost when men specialized in a profession of violence and combat assume supreme authority. On the other hand, the potential influence of the soldiers on the process of re-Africanizing African political culture might be regarded as a moral benefit. What is important is to stop the easy equation of relatively less educated soldiers with relatively westernized African intellectuals in power. Idi Amin of Uganda is simply not Milton Obote, nor is Achiempong of Ghana either Busia or Nkrumah.

In the struggle to give aspects of African culture greater respectability, young Africans themselves might have to start with the most ambitious of the tasks - the prior struggle to conquer African self-contempt. This in turn requires the growing toleration of some of the least respected, in western terms, of those aspects of indigenous culture. If an East African intellectual can begin to concede dignity to the physical nakedness of the Karamajong men, or to the use of red ochre on the skin of the Masai, or the invocation of supernatural forces to help determine an election, that African intellectual is on his way to transcending his own cultural self-contempt.

Some of the soldiers in power provide precisely that kind of challenge to the new generation of westernized and semi-westernized Africans.

Field Marshal Idi Amin has been a particularly severe test for large numbers of African intellectuals. Many seem to have been more ashamed of Amin's "superstitions" than of his political brutality, more worried by Amin's distance from normal western diplomatic style, than by how many Ugandans he had detained or eliminated, even more ashamed of Amin's "brazen polygamy" than his political arbitrariness.

David Martin, in his book, General Amin, has drawn attention to the prevalent nature of witchcraft and sorcery among Africans in different parts of the continent. Martin has also reminded us that it is not unusual to find "highly educated Africans visiting witch-doctors" in a bid to ensure promotion to better jobs. But, according to Martin, Amin had "taken his belief in occult powers to a ridiculous extent". He refers to a Zambian seer Dr. Ngombe Francis, who claimed to have predicted the overthrow of President Milton Obote. After the coup the Zambian prospered significantly, and became Amin's soothsayer and prophet. There was also the Ghanaian mystic who claimed power to raise people from the dead. The mystic was flown to Uganda, and Amin later asserted that he had had an opportunity to talk to a man who had so risen from the dead.

As for Amin's innumerable dreams, these have ranged from a dream about when precisely he would die, to his assertion that God had told him in a dream to expel the Asians from Uganda and launch a national economic war.

David Martin, a westerner, regards Amin's beliefs in occult powers as 
"ridiculous". It would be illuminating, were it possible, to find out how many of the less educated and less westernized Ugandans would share David Martin's views on the matter. It is conceivable that every time Amin has proclaimed a major dream, it has at best been Ugandan intellectuals that have laughed secretly. Some of the other Ugandans might dispute the validity or authenticity of this or that particular dream claimed by Amin, but perhaps the great majority would not dispute the proposition that some dreams are intended to be guides for action, and that supernatural forces might at times be in communion with a leader. ${ }^{11}$

But is it good for political culture in East Africa to have such beliefs resurrected? Would it add to the viability of East African political systems to invoke occult powers for policy-making?

This writer, as a westernized or semi-westernized African intellectual, has strong reservations about some of Idi Amin's political "superstitions". It is arguable that such beliefs from Africa's indigenous heritage deserve to die quietly, just as similar beliefs died previously in most parts of Europe. And yet, the very "ridiculous" nature of such beliefs to westernized African intellectuals provides a challenge to their own cultural self-contempt, and might at least increase their sympathy and understanding for many of their rural compatriots.

The late Oxford political philosopher, John Plamenatz, once asserted:

"The vices of the strong acquire some of the prestige of strength."12

As the rustic soldiers have acquired power, and demonstrated their political strength, perhaps some of the prestige of that strength might rub off on the peasant warriors' cultural "weaknesses".

The current generation of adult westernized African intellectuals might never be able to fully transcend their cultural self-contempt, but the next generation of educated Africans might have learned from their military rulers the capacity to understand and sympathize with certain aspects of the culture of the villages. Some of these beliefs in occult powers might die a natural death before long, but when African intellectuals can respect these, they will learn to respect other aspects of African culture as well.

\section{Re-Africanization of Africa and Militarized Ethnicity}

A related issue connected with the traditionalizing impact of the military on African societies concerns the whole issue of ethnic affiliation and loyalty. Does military rule aggravate or mitigate ethnic resurgence? How much "retribalization" takes place under the pressures of a politicized army? Again we must examine East Africa partly with a view to assessing likely trends elsewhere in the continent.

The colonial authorities in East Africa sometimes avoided certain com-

11 Consult David Martin, General Amin (London: Faber and Faber, 1974), p. 16.

12 Plamenatz, On Alien Rule and Self-Government (London: Longmans, 1960). 
munities in recruiting for the armed forces. The exclusion of such communities might have been motivated by considerations which ranged from a presumption that certain communities did not have either the valour or the physique for soldiers, to an imperial calculation that such communities when equipped with arms might create problems for the colonial order.

Persistent in the imperial mentality was the simple assumption that martial prowess was ethnically distributed. Some tribes were simply better warriors than others, they believed.

In the course of World War II, a new attempt was made in different parts of Africa by the colonial powers to assess the martial qualities of different communities, partly with a view to determining priorities in recruitment for the imperial armies against Germany, Italy and Japan. In East Africa some kind of research was conducted in this direction. The Chief Native Commissioner of Kenya asked that a census be undertaken to determine "the soldierly qualities of the members of the various tribes composing the East African Force." The issue was referred to a conference of governors of the East African colony, and a questionnaire was worked out and sent to each commanding officer in 1941.

"Each of the countries in East Africa was to furnish the Native Commissioner with names of tribes, giving provinces, districts. A similar survey, but a hasty one, had been carried out in 1932 'in order that opinions of K.A.R. Officers might be obtained with a view to deciding which tribes were likely to make the best soldiers."'13

Tarsis Kabwegyere reminds us of the questionnaire and the qualities which were looked for. These included adaptability, reaction to discipline, steadiness under bombing, stamina and staying power, powers of leadership, intelligence, esprit de corps, cleanliness and turnout, capacity for hard living, general health, ability to fraternize, and fighting qualities. There were in addition some special qualities and skills which were to be ascertained. Each ethnic group was assessed, and a system of scores for each was devised. ${ }^{14}$

But soldierly qualities had to be balanced against other considerations. Although in the early days of the colonial presence in Uganda the Baganda was still regarded as a martial community, there was an understandable reluctance among colonial administrators to recruit disproportionately from the Baganda into the armed forces. The Baganda were already becoming among the best organized and most politically conscious of the communities of the country. The imperial power naturally hesitated on the issue of militarizing the Baganda by giving them a disproportionate present in the imperial armed forces.

Both those who were excluded from the armies and those who provided the bulk of the army were chosen substantially in terms of ethnic categories. This basis of recruitment was to have considerable repercussions in the relations between soldiers and civilians after independence.

The different communities and tribes themselves entertained stereotypes

13 Gited by Tarsis B. Kabwegyere, The Politics of State Formation: The Nature and Effects of Colonialism in Uganda (Nairobi: East African Literature Bureau, 1974), p. 115.

14 Ibid., pp. 115-117. 
about each other, sometimes influenced by considerations about which community was capable of providing better soldiers. In Nigeria, the armed forces had recruited from both the north and the south, yet within the armed forces themselves mutual ethnic stereotypes conditioned interaction between different sections and ranks in the army.

"Northern soldiers obeyed orders from Ibo officers, but there was a residual feeling in their minds that the Ibo were not really a martial race-they considered the Ibo people too articulate for warriors. 'Maif ada ba zai yi surutu ba'- 'The warrior is not talkative'is a common Northern proverb; they regarded the martial qualities of the Easterners rather as the British other ranks regarded those of the Italian, or the Punjabi regarded those of the Bengali or the man from Madras." 15

Against this background both of an ethnic basis for the recruitment of soldiers into the armed forces and the persistence of ethnic stereotypes, the precise composition of the military by the time of independence in many African countries carried all the potentialities of ethnic resurgence.

Some scholars have argued that colonialism did not simply create new potential national states; it also created the tribes themselves. Groups that never before considered themselves as a cohesive political community were converted into one such community by colonial methods of administration. Kabwegyere cites some examples, including that of the Acholi in Uganda who were later to be regarded as a particularly martial community and provided a disproportionate number of soldiers for the Uganda Army in the days of Apolo Milton Obote.

"Present day Acholi is a result of an ordinance in 1937 which amalgamated both Chua to the East and Gulu to the West.... People in these two districts knew themselves more in terms of their clans, e.g. the Payira, Patiko, Padibe, etc. than in terms of a collective identity, the Acholi. The clans were the units for collective identity but not for collective action since clans were rarely occupants of a homogenous territory although they had a common culture.... It was Barrell the administrator in Gulu who finally gave the amalgamated District the name Acholi. 'I can think of no better name for the new District than the 'Acholi District'; there is no native name for the country as a whole...."16

Administrative convenience in the colonial period thus helped to bring together clans that previously never engaged in collective action, nor were they subject to the same collective administrative authority, into a pattern of relationships which now created ethnic-wide political consciousness. The Acholi began to see themselves as an amalgamated community, although tensions between clans continued, and divisions between east Acholi and west Acholi have persisted ever since. Field Marshal Idi Amin moved further towards dividing the east and the west once again, but what matters from the point of view of the

15 M. J. Dent, "The Military and Politics: A Study of the Relation between the Army and the Political Process in Nigeria," Robert Melson and Howard Wolpe (editors), Nigeria: Modernization and the Politics of Communalism (East Lansing: Michigan State University Press, 1971), p. 373.

Ibid., pp. 43-45. 
colonial genesis of "tribalism" is the simple fact that a broad new Acholi political consciousness became superimposed over the narrower parochialisms of the sub-units of the Acholi.

By the time Obote was overthrown, the Acholi constituted the largest single group within the Armed Forces of Uganda, although in relation to the rest of the population they were clearly one of the smaller groups of Uganda. Between a third and a half of the Ugandan army consisted of Acholi.

Their preponderance was partly an outcome of their categorization as a tribal unit in the colonial period, and partly the outcome of their presumed martial qualities.

Related to this second presumption was simply the issue of physical height. As an ethnic community the Acholi and other northern tribes of Uganda had produced a disproportionate number of tall people. Since recruitment into the Uganda armed forces gave preference to candidates who were $5^{\prime} 8$ " or over, the northern communities had a prior edge in physical anthropology. Among the northerners, the Acholi enlarged after a while this edge in terms of actual recruitment into the armed forces.

By the time Amin captured power from Obote, Amin was all too aware of the preponderance of the Acholi within the armed forces. Would these be loyal to the new regime under Amin or would they maintain a prior loyalty to Milton Obote? Amin's reasoning in terms of determining potential allies was again couched in ethnic terms. He himself is a Kakwa, from a relatively small group in Uganda, though it extends substantially across the border into the Sudan, with ethnic compatriots also across the border in Zaire.

In his early announcements as to why the coup took place, Amin asserted that the Acholi, in alliance with Obote's own tribe, the Langi, had plotted to disarm all other soldiers, and assert a complete ethnic monopoly of military power in Uganda. Thus tensions against these two communities started from the early days of Amin's assumption of power. Since then thousands of Acholi and Langi have perished in the wake of Amin's political and military insecurity.

Almost every year since he took over power in 1971, issues of ethnicity have been profoundly interlinked with issues of domestic balance of power. In July 1974, the Acholi and the Langi were once again singled out by spokesmen of the Amin regime as plotters against his government. It was asserted that they were waiting for an invasion of pro-Obote refugees from Tanzania. The domestic Acholi and Langi would provide internal support as the refugees from across the border sought to undermine and then overthrow the government of Idi Amin. Many Acholi and Langi in Uganda decided to flee the country in the wake of these renewed accusations. Ethnicity in Uganda had worn once again the ominous face of militarized revenge and brutality.

Among those Ugandans in exile in Tanzania, ethnic factors were also at play. Even when they plotted to invade the country and overthrow Idi Amin's government, the Ugandan exiles were sometimes torn by their own ethnic cleavages. The Langi were at times at variance with the Acholi. And even on the eve of the joint invasion of Uganda in September 1972, the internal strains 
were not entirely absent. Old traditions within each community affected their behaviour in exile. Just before they departed on their ill-starred adventure against Amin in September 1972, the old soldiers in exile in Tanzania invoked an Acholi war dance and song, a ceremony of consolidating courage and inspiring confidence. Some of those who were to be joint fighters in the attempted invasions were irritated by the Acholi traditional war ceremonics in preparation for this collective enterprise. But the war dance and song, the invocation of Acholi martial symbolism, captured both the tensions of ethnicity and the resilience of indigenous traditions. 17

But is this kind of militarized situation more bedevilled by ethnic factors than a situation of civilian politics? The answer varies somewhat from one African country to another. But, to the extent that in most African countries recruitment into the armed forces was more ethnically specialized than participation in civilian politics, the military situation had graver ethnic risks than the civilian political system. Certainly in Uganda, politics in the first eight years of independence was a more ethnically representative phenomenon than access to military careers. Parliament, the Cabinet under Obote, and increasingly the civil service, provided more of a cross-section of the different communities of Uganda than the armed forces could ever claim. The process of political mobility, in the sense of different regions and tribes having some access to effective political participation and representation at some level or another, was more convincing when political power depended on the interplay of civilian pressures than when it came to depend upon the balance of ethnic factions within the armed forces.

In the latter situation, clearly there is a greater potential explosiveness of ethnic factors than in a situation of civilian contests of will. This is not to underestimate the tensions involved in politicized ethnicity. All that we are trying to demonstrate is that militarized ethnicity, partly because of the selective nature of recruitment into the armed forces, has a higher potential for "retribalization" than politicized ethnicity.

Those who blame both tribalism and the creation of nation-states on colonialism do have a point, but what they often overlook is that tribalism might be an outcome of the creation of the nation-state. Whether or not British colonial authorities explicitly began to categorize the Acholi as one community, those Acholi would have begun to think of themselves as such as soon as they saw themselves in competition with other groups for the limited resources of a new territorial entity called "Uganda". What is being claimed in this assertion is that it was the exercise of bringing together divergent linguistic and cultural

17 David Martin refers to the irritation of the younger exiles over the Acholi war dance and song in the preparation for the invasion of Uganda. Martin seems to suggest that it was the younger, modernized or westernized soldiers in exile, who were particularly unhappy about such a ceremony. In fact, in addition to the reservations of the more modernized or westernized of the exiles, there were also reservations on the part of those who belonged to other ethnic communities. For Martin's allusion to this episode consult his General Amin, op. cit., pp. 189-190. 
groups within the boundaries of a new state which generated new levels of ethnic consciousness. Even if the British had not explicitly bracketed the different clans into a new community called Acholi, the forces of competition within the national system of Uganda would have resulted in the discovery among the Acholi of a shared culture and language. This ethnic consciousness was almost bound to be sharpened in the scramble for a share of what independent Uganda as a new political community had to offer to its constituent parts.

The attainment of independence did not redraw the boundaries of the new nation-state. The persistence of ethnic consciousness and ethnic identity had therefore to be related directly to the continuation of the new national boundaries. In Uganda, as elsewhere in Africa, it was not simply a case of the new nation-state lacking a transethnic identity and legitimacy of its own. It was a case of the very presence of such a nation-state lending legitimacy to the ethnic sub-units and strengthening parochial loyalties.

In some African countries under military rule the extent of retribalization might for a while be disguised by the appearance of a firm political order with "iron discipline". But ethnic resurgence does take place as soon as the iron military grip begins to loosen, or even when civilian rule is restored after a period of military control. Ghana under Kofi Busia did witness a resurgence of ethnic particularism following the rule by the National Liberation Council. At best, a military regime succeeds in putting ethnic cleavages in a society in "cold storage". At worst, military rule, partly because of the pattern of recruitment into the armed forces and partly because of the nature of army rule itself, simply degenerates into eruptions of militarized ethnicity with periodic violent confrontations. This process of retribalization is indeed an aspect of retraditionalization, but with a heavy political cost.

\section{Cattle-Raid Complex Under African Militarism}

But why is the level of mutual brutalization in some African societies so high? Why does retribalization under military conditions carry such a heavy risk of killing and counter-killing? Again East Africa's experience falls considerably short of being unique. Evidence of mutual brutalization is already available elsewhere in the continent.

One part of the answer is simply that the different ethnic groups in an African country are not always ready to regard each other as anything more than rival "nations" next door. An African country becomes a kind of international system in miniature, with ethnic groups behaving in part as if they were autonomous little states in their own right competing for scarce resources. Unlike the broader international community, an African country does normally have a government in power; but even that power at the center is regarded as a scarce resource which the different contending parties seek to control or at least to share. Those who actually do possess the scarce resource of central political power find themselves strongly tempted not to share it except on the basis of special alliances. Favoritism, ethnic nepotism and ethnic 
competitiveness play their role in creating inequalities and disequilibrium in the distribution of political goals.

But the old warrior tradition also intrudes and conditions attitudes, especially in situations where soldiers attempt to monopolize the central institutions of power. In many East African societies the old warrior tradition was based not simply on the ambition to maintain collective security, but also on the ambition to foster collective prosperity. The warrior was not simply a person who waited until his cattle or his women were attacked before using his military skills for defensive purposes. On the contrary, the warrior was also a person who considered economic competition as being not primarily a rivalry between individuals or sub-groups within the same society, as competition is taken to be in western capitalist countries, but more a continuing dialectic of rivalry with alien or semi-alien societies nearby. Out of this concept emerged cattle-raiding and similar forms of militarized economic acquisitiveness as an aspect of the warrior ethos.

"The experience of warriorhood during adolescence helped in transforming an Embu boy into an Embu man.... The tradition of raiding for live-stock was strong in the cluster of societies in the area, and the Embu trained their young men both to protect their own herds from enemies and also to raid the neighbouring peoples.... Raiding enemy tribes for live-stock (and women) and in the process achieving fame in fighting were dominant concerns of warriorhood in Embuland. The first raid was important for a young man, contributing to the legitimization of his new role." 18

The idea by which members of a community found it legitimate, and indeed part of the duties of warriorhood, to take economic advantage over other ethnic communities was something which was bound to affect the behaviour of soldiers in uniform in the post-colonial era.

Many commentators on African behaviour have too readily assumed that the reference point for African soldiers was always and inevitably the imperial model. But is the behaviour of African privates in Nigeria or Uganda really like the behaviour of British privates, or does it bear closer affinity to the behaviour of traditional warriors? Is the soldier in Zaire more reminiscent of a Belgian soldier than of a pre-colonial Congo or Luba warrior?

Robert Price once invoked psychological categories to explain the apparent attempt by African soldiers to emulate the imperial military model. Price used reference group theory to explain what he called "the emulation paradox".

"An individual's reference groups are those social groups to which he psychologically relates himself, with which he identifies. To become a member of the group in a psychological sense implies the internalization of its central norms and values-for to be a member implies certain modes of thought and behaviour."19

18 Satish Saberwal, The Traditional Political System of the Embu of Central Kenya, op. cit., pp. 17, 29.

19 Robert M. Price, "A Theoretical Approach to Military Rule in New States: ReferenceGroup Theory and the Ghanaian Case," World Politics, Vol. XXIII, No. 3, 1971, pp. 403-404. 
Applying the theory to the Ghanaian military especially, Price argued that the training process undergone by the officer corps was "such as to produce reference-group identifications with the officer corps of the ex-colonial power and the concomitant commitment to its sets of traditions, symbols and values." 20

For a while it might have been true of the officer corps that the most immediate reference group was that of the former colonial power, but writers like Price may have underestimated the resilience of traditional norms among the great majority of African soldiers. Certainly many East African soldiers come from societies that still have initiation ceremonies based on ancestral warrior ideas, though currently no longer translated into actual practice. The socialization processes of many of these societies continue to emphasize particular primordial concepts of courage, masculinity, and attitudes to rival ethnic groups. There is comparable evidence elsewhere in Africa that among the categories that could be resurrected from the ancestral past is simply the "cattle-raiding complex" - the concept of militarized economic competition between collective social units.

"The extensive participation of Habe (non-Fulani Hausa) and Fulani in slave-raiding and war was achieved by mobilizing contingents from the fiefs; and military action offered such troups rewards in the form of booty, appointments and promotion. The frequency and success of this military adventure may have persuaded many people to support the system of government. Since political and administrative office provided the principal means of enrichment and social mobility together, and had clear military commitments, the recruitment of officials for these expeditions presented no problems." 21

In East Africa this "cattle-raiding complex" was exploited by the Europeans in the initial stages of their own conquest of the region. The British in Uganda, for example, economized on their own military expenses by recruiting African soldiers and letting them do some looting on the way for compensation.

\begin{abstract}
"It was important to capture cattle, goats, etc. from the conquered people; this was food for the soldiers.... The great number of soldiers with the few British officers, moving with goats, cows, etc. must have been spectacular and frightening. The few officers could not control the multitude of soldiers especially when they were hungry.... Thus the soldiers were not only top-dog on the power of the gun dimension, they also had economic power. It is difficult to measure the social disequilibrium that was caused by relative deprivation among the people by the presence of the rich gunmen." 22
\end{abstract}

This phenomenon of "rich gunmen" late in the nineteenth century and early in the twentieth century anticipated a major trend in the Africa of the 1960's and 1970's upon the withdrawal of the European masters. The cattleraid complex first had bedevilled relations between African ethnic groups, was later exploited by the imperial power, and has now begun to condition the appetites, acquisitiveness, and ethnic attitudes of African soldiers in power after independence.

20 Ibid., p. 407.

21 M. G. Smith, Government in Zazzu (London: Oxford University Press, 1960), p. 100.

22 Kabwegyere, The Politics of State Formation, op. cit., pp. 73-74. 
What this means is that there are aspects of the re-Africanization of Africa which might not be specifically functional or beneficial. That these aspects are retrograde from the point of view of justice and inter-ethnic amity in African countries does not invalidate the proposition about the traditionalizing impact of the phenomenon of under-educated Africans wielding considerable political power in political communities much larger in size than their orginal ancestral societies.

\section{Decolonization and Cultural Nationalism}

But although certain aspects of re-Africanization are immensely costly in human terms in the short run, the process of retraditionalization in totality might well be a fundamental aspect of decolonization. Much of the previous literature on modernization in Africa too readily assumed that the road to political development was through westernization. Political development was envisaged in terms of building institutions comparable to those of western systems, and consolidating values and styles derived from western cultural experience.

But with the growth of a new rival literature based on the concept of dependency the whole concept of "development" has been either rejected or drastically redefined. Where it has been redefined, development is now conceived in terms of a progressive reduction of dependency, a commitment to practical decolonization not only politically but also economically and culturally. ${ }^{23}$

While some writers have emphasized economic decolonization, this writer regards cultural decolonization as more fundamental than many have assumed. Mental and intellectual dependency, a lack of readiness to break loose from the metropolitan power, a compulsive urge to imitate and emulate what the West has produced, are factors which have on the whole had grave economic and political consequences for societies which are still unwilling to take drastic decisions for their own transformation, but they are also phenomena with deep cultural causes. The lack of a political will for an economic transformation might in part be due to a state of mental and cultural dependency.

From this point of view then, trends towards retraditionalizing Africa become as aspect of decolonization. In reality, Africa is never likely to move to what it was before the European came. In hard assessment, it would be suicidal if Africa attempted such a leap backwards. But a partial retreat towards renewed respect for indigenous ways, and a conquest of cultural self-contempt, might be some of the minimal conditions for cultural decolonization.

23 Some of the works by Samir Amin, Johan Galtung, Walter Rodney and Colin Leys are among those which belong to this new genre of developmental literature. Perhaps the most sustained and most recent application of this radical perspective to an African country is Colin Leys' book Underdevelopment in Kenya, (London: Heinemann Educational Publishers, and Berkeley: University of California Press, 1975). 
Again soldiers in power, sometimes naively, have often taken some of the most drastic decisions towards decolonization in this domain. Mobutu Sese Seko's drive to resurrect African authenticity in Zaire is one case in point. The General has had tense confrontations especially with the Catholic Church over aspects of the church's influence on the cultural ways of Zaireans.

Among the more dramatic symbolic moves made by Mobutu Sese Seko was the decision to compel all Zaireans to have indigenous names, rather than European or Jewish names adopted at baptism. The General argued that a religion which aspires to be universalistic must be ready to recognize cultural pluralism in the world. Why should Christian names necessarily be of European or Jewish extraction? Why could not indigenous African names qualify for baptismal status in their own right? Why did God have to despise every aspect of indigenous African cultures, down to the names which parents chose for their children?

An order went forth required all Zairean citizens to ensure that their passports had Zairean names. The President himself renounced his baptismal name of "Joseph". Many other Zaireans were deeply torn by this decree requiring them to give up European or Jewish names they had carried all their lives. Many understandably regarded this as an intrusion into a deeply personal affair. And yet the cultural nationalism which made Mobutu require his compatriots to respect indigenous names, and the Catholic Church to be more respectful of local cultures, was pregnant with the symbolism of cultural revival.

The authenticity drive in Gaddafy's Libya also included a preoccupation with passports. But in the case of Libya, the ambition was not simply to force the local citizens to do justice to their heritage, but also to demand reciprocity in cultural respect from the international community at large. Visitors to Libya were required to have passports which included the use of Arabic. Why after all should the language of passports all over the world be so disproportionately based on the linguistic heritage of western Europe? Why must Arabs and Africans have to use French or English as one of the languages of their travel documents, while the French and the English made no reciprocal linguistic concession to the customs officers at Arab or African ports?

There are of course a large number of practical reasons why the world has had to bow to English and French as the most widespread of the languages of mankind. But there are also important issues of cultural reciprocity involved in that simple gesture by Colonel Gaddafy in Libya to force visistors to Libya to have travel documents legible and intelligible to Libyan immigration officers in the national language of Libya itself.

In Uganda, some modifications in the marriage laws of the country, including greater recognition of polygamous relationships, have also been part of the stream of retraditionalization. So was the adoption by President Amin of Kiswahili as a national language of Uganda, in spite of the fact that the language is less well known that it is in either Tanzania or Kenya, and in spite of the immense educational difficulties which would be involved in implementing this linguistic decision. 
Even the ruthless expulsion of influential foreigners, with all the lack of humaneness involved, could also be seen as part of the process of decolonization.

"Colonel Gaddafy, deeply concerned about foreign penetration of the culture and economy of the country, decreed a host of steps; seizure of Italian and Jewish property without compensation; announcement that all business concerns, save oil companies, must be owned entirely by Libyan nationals; nationalization of banks and public transport; emphasis on Islamic standards." 24

Gaddafy's expulsion of the Italians was later followed by Idi Amin's expulsion of the Asians from Uganda. Both moves could only have been done under a military regime, with all the relative insensitivity to the diplomatic and humanitarian implications of those measures. Certainly the British fear of Idi Amin at the time of the expulsion of the Asians emanated from the very fact that he was a soldier in charge of a rather undisciplined army, and was capable of taking physical action against British Asians and even British Europeans in Uganda in a manner which would have been inconceivable under Milton Obote. Once again the rugged and semi-literate nature of the military regime was a factor behind the expulsion of those influential aliens, and that expulsion in turn could be seen as part of the ruthless and painful process of decolonization.

The total picture in Eastern Africa is still incomplete with regard to the retraditionalizing role of African soldiers. The concurrent process of modernization must always be taken into account in evaluating these issues.

But a convergence of four factors should alert us to the current or potential re-Africanizing role of the armed forces in Africa. These factors include the rural and parochial origins of most of the recruits into the armed forces, the minimal acculturation of the soldiers as compared with the better educated civilian populations, the ethnic patterns of military recruitment with the potentialities of retribalization, and the partial resurrection of the warrior tradition. ${ }^{25}$

\section{Conclusion}

On the whole the cultural influence of Europe is of longer duration in West Africa than it is in places like Uganda, Zaire and Kenya. In the field of both civilian and military education that has meant a longer tradition of college, university and Sandhurst training in Ghana and Nigeria than among Africans on the eastern seaboard.

24 Claude E. Welch Jr., "Radical and Conservative Military Regimes: A Typology and Analysis of Post-Coup Governments in Tropical Africa," paper prepared for delivery at the 1973 Annual Meeting of the American Political Science Association, New Orleans, Louisiana, September 4-8, pp. 13-14. Since, the oil has also become increasingly subject to state ownership and control.

25 Consult also Ali A. Mazrui, "The Resurrection of the Warrior Tradition in African Political Culture: From Shaka the Zulu to Amin the Kakwa," presented on the panel on "Terrorism and Politics in Africa," Sixteenth Annual Meeting of the African Studies Association of the U.S.A., held at Syracuse, October 31-November 3. 
If there is a process of westernization still going on in Africa, one would expect West Africa to be further ahead than East. Political scientists in the 1950's were therefore taking a justifiable gamble when they regarded the growth of western-style nationalistic movements in West Africa as a harbinger of comparable movements elsewhere.

On the other hand, if there is now an inchoate but insistent reassertion of indigenous political values at the highest level of government, it is perhaps less likely to have started in sedate and highly anglicized Ghana than in tumultous Zaire, in the Central African Republic and among the Nilotic and Sudanic peoples of Uganda.

Let us now draw out the tentative hypotheses which lie in these observations. We may, in other words, hypothesize that everything else being equal the process of "modernization" in the western sense is likely to go fastest in those societies which have experienced the deepest western impact either in duration (Ghana and Southern Nigeria) or terms of proximity to white settlers (Kenya, Rhodesia and South Africa).

By contrast, the process of political retraditionalization is likely to start first in those societies which have had least time to adjust to the impact of the West. By "political retraditionalization" we mean here concrete attempts to formulate policies either under the influence of indigenous mores or in pursuit of ends defined according to indigenous criteria. Zaire and Uganda are cases in point.

The third compound hypothesis is that military rule in Africa has consequences which are both modernizing and traditionalizing. Built into this compound hypothesis is the expectation that military rule in a place like Ghana (high acculturation) would reveal its traditionalizing role more slowly than military rule in the hands of the Kakwa and Lugbara in Uganda (low acculturation). But since the bulk of the army of Ghana also consists of men of relatively low acculturation, each successive coup in a place like Ghana would bring up more of the less westernized Ghanaian soldiers into prominence. The first Ghanaian coup was more "Sandhurst and British" than the second. The third, should it take place, would be less "British" still. The difference between Ghanaian soldiers in power and Ugandan and Zairean soldiers in power will probably narrow, without necessarily ending.

Our fourth compound hypothesis concerns a comparison between civilian and military rulers in Africa. We agree that there is no evidence yet that soldiers are greater modernizers than the civilians they replaced. But the evidence from East Africa would seem to suggest that soldiers may be greater traditionalizers than the more westernized civilians they ousted. For better or for worse, this is certainly true of Idi Amin as compared with Milton Obote, and true of Mobutu Sese Seko as compared with such figures as Kasavubu and Moise Tshombe.

But how do these factors relate to the experience of a country like Ethiopia? The balance between the modernizing and the traditionalizing functions of soldiers has to be different in Ethiopia, partly because of the ancient ancestry 
of the traditional imperial system while it lasted, and partly because of the brevity of Ethiopia's colonial experience under Italian occupation. There were aspects of the traditional imperial system in Ethiopia which were so anachronistic that almost any major military challenge to it in the second half of the twentieth century was bound to have a conspicuously modernizing aspect.

Yet even in Ethiopia it would be surprising if the performance of the army did not gradually manifest once again a compulsive urge to retraditionalize aspects of Ethiopian life. Without being directly ruled by the West for any length of time, Ethiopia under Haile Selassie had been partly absorbed into the Western world's strategic empire. The literary presence of the United States in the country, and the increasing cultural orientation toward the West which the imperial elite manifested, had started a process of westernization at that level of Ethiopian society. If the Ethiopian soldiers were now to embark more earnestly on both decolonization and democratization, the former process might well include a theme of cultural nationalism and traditionalization. The latter process of democratization, on the other hand, would correlate closely with modernization in Ethiopia.

In this regard the experience of Libya would turn out to be a precedent for Ethiopia. The military overthrow of King Idris of Libya created a radical change in the country. Domestically the soldiers did inaugurate a process of at least structural and economic democratization, as educational opportunities were vastly expanded, foreign economic control was reduced, and the wealth of the country was used more extensively for the welfare of the masses and the development of the country.

But while the soldiers' impulse to democratize Libya after King Idris has initiated modernization, their urge to decolonize Libya has resulted in a new Islamic fundamentalism. Economic democratization in Libya has increased a consciousness of the future and the need to plan for it. Cultural decolonization, on the other hand, has awakened memories of the past and rekindled an interest in protecting its heritage. Both modernity and tradition have provided reasons and motivation for reform in Libya after the monarchy. Both might also instigate radical change in a post-imperial Ethiopia.

Behind both examples lies the partially disguised but sociologically fundamental tendency of soldiers in Africa to respond to their rural, social and cultural origins. Either wittingly or through the mysterious sense of direction of unconscious behavior, African soldiers are becoming media for the selective re-Africanization of the countries they rule. 